\title{
The Development of Geothallus tuberosus, Campbell.
}

\author{
BY
}

D. H. CAMPBELL, Ph.D.

Professor of Botany in the Leland Stanford Junior University, California, U.S.A.

\section{With Plates XXIV and XXV.}

T N the spring of $\mathrm{I} 895$ the writer received from San Diego 1 specimens of a Liverwort which on examination proved to be so different from any described form, that it seemed necessary to establish a new genus to contain it. A preliminary account of the plant was therefore published $^{\mathbf{1}}$, in which the name Geothallus tuberosus was proposed for it. The first lot of specimens were sterile; but later, through the kindness of Mrs. Katherine Brandegee, from whom the first lot had been received, fruiting plants were secured which proved conclusively that the plant represented a very low type of Hepatic, whose sporogonium was very much like that of Sphaerocarpus, a common Liverwort of the whole coastregion of California.

When first received, the plants had about completed their season's growth and were beginning to dry up. The thallus was partly buried in the light sandy earth in which they were growing, and they were quite overlooked at first. They were growing with plants of Ophioglossum mudicaule, and

${ }^{1}$ Campbell, A New Californian Liverwort, Botanical Gazette, Jan. I896. [Annals of Botany, Vol. X. No. XL. December, 1896.] 
when the latter were received they were placed under belljars to keep them fresh. The moisture started the Liverworts into growth, and their peculiar form at once attracted attention. When first seen, they were little fan-shaped fimbriated shoots, entirely different in appearance from any Liverwort with which the writer was acquainted. Further investigation revealed the presence of peculiar tubers, almost completely buried in the ground, from which these green shoots were evidently derived. A number of these were kept growing and developed imperfect reproductive organs, but these belated shoots did not develop in an entirely normal manner.

A considerable number of the tubers were allowed to dry in the earth where they had been growing, and were kept in this condition through the summer. In the autumn some of these were placed in water and germinated promptly. Repeated plantings were then made from time to time, and a good supply of normally developed plants was secured which made it possible to trace through the life-history of this interesting form with a fair degree of completeness, although a few points, notably the germination of the spores and the later stages of the embryogeny, were not as completely made out as might have been wished, owing to the limited amount of material. The results of these observations are given here, together with the conclusions based upon them as to the systematic position of Geothallus.

\section{Germination of the TUbers.}

The tubers, to which reference has already been made, constitute one of the most characteristic features of the plant. My attention has been called to a reference by Leitgeb ${ }^{1}$ to what seem to be similar structures in the genus Petalophyllum, but no account was given of their structure or development. The thallus of Petalophyllum ${ }^{2}$ is also said to be partially buried in sandy soil like that of Geothallus.

${ }^{1}$ Leitgeb, Untersuchungen über die Lebermoose, iii. p. I 26.

${ }^{2}$ Schiffner, Hepaticae, in Engler and Prantl, Die Natiirlichen Pflanzenfamilien, 9I, $9^{2}$, p. 59. 
The ripe tuber in Geothallus is an oval, more or less flattened body, consisting of a mass of parenchyma densely filled with opaque granular contents, containing much fatty oil, but little starch. This mass of cells is surrounded by a layer of firm black cells, outside of which is a loose mass of dried-up parenchymatous tissue. A section of the ripe tuber (Fig. I) shows at once that the bulk of it is derived from the central part of the thallus, and that the dark-coloured cells composing the inner rind are interrupted in front, where the growing-point of the thallus persists unchanged. The loose outer investment of the tuber is simply the remains of the leaves and the outer tissues of the thallus.

The anterior end of the tuber is free, and a longitudinal section shows that the apical cell of the shoot is still recognizable (Fig. 3, $\times$ ). The regular segmentation is perfectly obvious, and is in no way different from that of the actively growing thallus. The apical cell and the younger segments cut off from it do not contain so much of the granular matter which renders the other cells of the tuber so opaque. The nuclei of the cells are of moderate size, but perfectly distinct and readily seen. The mass of cells making up the tuber is sharply marked from the outer tissues of the thallus by one or two layers of cells with thick black walls (Figs. I, 2), and the growing-point is protected by the overlapping marginal lamellae or leaves with which the plant is provided. The fullgrown tuber is from I to $2 \mathrm{~mm}$. in length, and about half as wide.

The first experiments in germinating the tubers were made in September, and others were made at intervals during the autumn and winter. The tubers were taken from the earth, and after removing most of the dead tissue about them, were placed in a glass vessel with just enough water to cover them. The first lot of tubers was put in water on September $2 \mathrm{r}$, and on October 3 the green shoot was first seen. A second lot was placed in water on October 4, and on the gth the young green shoots were already plainly visible. The best results and most vigorous plants were obtained from the germinations 
made during October, November, and December, which is probably the natural period of germination. Those started later germinated less promptly, and in most cases failed to develop perfect reproductive organs. Where the tubers were placed in earth at once, they failed to germinate, at least early in the season, but what the explanation of this is it is difficult to see. It was found best to allow the tubers to remain in water until growth was well commenced, and then to transfer them to earthen saucers filled with sandy soil similar to that in which they originally grew. These saucers were placed in others filled with water and the top covered by a pane of glass. In this way abundant moisture was supplied, but evaporation was not prevented, as is the case under a bell-jar, and the plants grew much better than when grown in an absolutely saturated atmosphere.

As soon as the tuber is placed in water it absorbs the moisture rapidly, and the activity of the cells in the apex is almost at once resumed. Within two or three days the cells of the growing-point usually show more or less chlorophyll, which is quite absent from the cells of the ripe tuber. With the development of chlorophyll there begins an active growth in the apical region, which grows out into a green shoot which is very soon recognized as the first stage of the young thallus. This shoot is somewhat heart-shaped when seen from above (Fig. 5), and its margin is strongly fringed and lobed. From the lower cells numerous fine rhizoids with delicate, colourless cell-walls grow out, and, if the plant is now placed upon earth, quickly fasten the young thallus to the ground. As the thallus develops, the supply of reserve food in the tuber is rapidly exhausted, and the tuber finally decays. As it is very easily broken off it was overlooked when the plants were first discovered.

As the plant grows, there are formed from the margin structures which can only be designated leaves. These are formed in regular succession on either side of the growingpoint, and recall strongly the similar organs in Fossombronia or Petalophyllum. These leaves are very conspicuous, espe- 
cially when the plants are growing under glass, and give the plant an exceedingly characteristic appearance. In addition to the marginal lamellae or leaves, there are frequently formed similar outgrowths upon the dorsal surface, which, however, do not appear to bear any direct relation to the leaves, and are extremely variable in number, size, and position.

\section{Apical Growth of the Thallus.}

A vertical section through the apex of the thallus, at any stage, shows the free surface of the growing-point to be nearly vertical, and near the middle is the apical cell (Fig. $6, \times$ ), which is small when compared with the typical anacrogynous Jungermanniaceae, and recalls more nearly, perhaps, that of the Marchantiaceae. It is deeper, however, than is usual in those forms, or in Sphaerocarpus, which also has the apical cell of the same type and is not so near the ventral side of the thallus. Alternate dorsal and ventral segments are cut off from this cell in the usual way; but on account of the rapid secondary divisions in them, the limits of the segments are much sooner lost than in Sphaerocarpus. Some of the superficial cells of the vertical segments form jointed glandular hairs, like those commonly found in the anacrogynous Jungermanniaceae. They are much larger than the corresponding ones in Sphaerocarpus, and are not usually formed so near the apex. They lie on either side of the median line, so that an exact median section may fail to show them. Each hair (Fig. 9) consists usually of a small basal cell, and a row of several others, ranging from two or three to five or six in exceptional cases. The terminal cell is enlarged, somewhat pear-shaped in outline, and filled with densely granular contents. The secretion of this cell is probably mucilaginous, and the whole cell in the older hairs stains very strongly with Bismarck-brown. No doubt the mucilaginous secretion serves as a protection for the growing-point against evaporation.

In sections of the growing-point made horizontally, the apical cell appears four-sided in outline, often somewhat 
narrower in front. It is not at all conspicuous, and is not always readily distinguishable from the adjacent segments. These are cut off from the lateral faces, apparently with considerable regularity, but their limits are soon lost. Comparing the horizontal section with the vertical section, it is evident that the form of the apical cell is that of a truncated wedge, from which four sets of segments are cut off, two lateral, one dorsal, and one ventral. It is in short exactly the same type as that of Riccia or Sphaerocarpus.

\section{The Leaves.}

The leaves arise as outgrowths of the superficial cells of the lateral segments, and apparently each segment gives rise to a leaf. They stand vertical at first, but later become more or less shifted, so that they are finally inserted obliquely. In horizontal sections of the growing-point (Fig. 7), the growing leaf $(l)$ appears as a simple row of cells. If a surface-view of the leaf is examined, however, it is then seen that the leaf is roundish and slightly pointed in outline. In some cases at least there was evidence of definite apical growth from a twosided cell, much like what obtains in the similar leaf-like lobes of the prothallium of Equisetum maximum. In other instances it looked as if the first wall of the mother-cell of the leaf bisected it and was followed by others at right angles to it (Fig. 8). In such cases there is probably no definite apical growth. As the leaf enlarges, the marginal growth is unequal, and the older leaves are often decidedly irregular in outline and deeply lobed, so that their original arrangement is obscured. The development of leaf-like outgrowths from the dorsal side of the thallus, which are often partially confluent with the true leaves, disguise still further the two-ranked arrangement of the latter. These dorsal lamellae, as well as the leaves themselves, are for the most part but a single cell in thickness, but the base is usually thicker, merging somewhat gradually into the body of the thallus.

In the original specimens sent from San Diego, the thallus 
was more or less wedge-shaped, but often nearly orbicular in outline. The plants were growing crowded together, and almost buried in the earth, and as they were beginning to dry up were not at all conspicuous and, as already said, were quite overlooked at first, and it was not until the moisture with which they were supplied started them into growth that attention was called to them. These plants were about 5 to $7 \mathrm{~mm}$. in length by 3 to $4 \mathrm{~mm}$. in breadth, and often quite unbranched, or only once dichotomous. The plants raised in the laboratory were usually somewhat larger than the original ones, and branched more freely. This greater vigour, as well as the more luxuriant development of the leaves, was no doubt owing to the great amount of moisture furnished them. The branching in all cases was a typical dichotomy like that found regularly in the thallose Liverworts.

In connexion with the freer branching and better development of the leaves of the plants grown under glass may be mentioned a similar acceleration of growth in Sphaerocarpus. A number of specimens of Sphaerocarpus terrestris var. californicus Aust. appeared in one of the cultures of Geothallus, and these differed so much from the normal plants as to be scarcely recognizable. They grew very vigorously and decidedly exceeded the normal plants in size. This was especially true with the male plants, which were several times larger than is usually the case. They branched freely, and developed unmistakable leaves, not unlike those of Geothallus, while the normal plants have the margin of the thallus quite undivided ${ }^{1}$.

The thallus of Geothallus is fastened to the earth by very numerous white rhizoids. These are outgrowths of superficial cells, and are thin-walled and colourless like those of most Jungermanniaceae.

In regard to the arrangement of the leaves, Geothallus resembles most nearly Fossombronia among the American

1 For particulars concerning these abnormal specimens of Sphaerocarpus, see a recent article by the writer in Erythea, May, $x 896$. 
genera of Liverworts. Some of the specimens examined strongly recalled $F$. longiseta, a common and characteristic Californian species. From Petalophyllum, with which Geothallus seems to agree in the general form of the thallus and arrangement of the leaves, it differs essentially in the absence of anything resembling the anterior leafless prolongation of the thallus described and figured by Leitgeb ${ }^{1}$. Unfortunately this genus does not occur in the United States, so there was no opportunity of examining the plants themselves for purpose of comparison.

Under favourable conditions the sexual organs were mature within a month from the time the dry tubers were placed in water. Those started in the spring and the first ones started in the autumn did not produce normal reproductive organs, although these began to form. Most of those started after January I also failed to mature the sexual organs, and in some of the plants grown from these belated plantings the reproductive organs were almost entirely wanting. Geothallus is dioecious, but there is not much difference in the size and general appearance of the male and female plants, in which respect it offers a strong contrast to Sphaerocarpus, where the male plants are very much smaller than the female.

In their position and general structure the sexual organs resemble those of Sphaerocarpus, and each archegonium or antheridium is surrounded by a separate envelope, that about the archegonium becoming very conspicuous. As a rule the sexual organs are produced less abundantly than in Sphaerocarpus, but are decidedly larger. The time of their first appearance varies a great deal, in some cases being evident when the young shoot was not more than a millimeter in length; but in most cases the young thallus had reached a length of several millimeters before the youngest ones were to be detected. Where the development of the sexual organs was partly suppressed, the envelope was not usually fully developed, and projected but slightly above the surface of the thallus, recalling the simple pores of many Marchantiaceae.

${ }^{1}$ Leitgeb, 1.c., iii. p. I 26, Pl. IX, Figs. r6-19. 


\section{The Antheridium.}

There is a considerable variation in the form and size of the male plant, as well as in the number of antheridia produced. The thallus may remain unbranched (Fig. IO), or it may fork once or twice. No definite relation between the young antheridium and the segments of the apical cell could be discovered. As the young antheridia seldom stand exactly in the median line of the thallus, and are usually more or less inclined forward, exact median sections are not always easy to get; but by cutting the thallus at different angles it was possible to obtain a series of slides which showed most of the different stages of development.

The antheridium mother-cell (Fig. II) is very early distinguishable from the neighbouring superficial cells of the thallus, and is formed further back from the apex than is the case in Sphaerocarpus ${ }^{1}$. It is an elongated cell which projects strongly above the adjacent cells, and its nucleus is decidedly larger than the nuclei of the neighbouring cells. The protoplasm is also denser, but the cell contains several large vacuoles. The first division-wall is horizontal, and nearly on a level with the surface of the thallus. This is followed by a similar division in the upper cell, dividing it into two of unequal size (Fig. I2). The original cell is thus divided into three superimposed cells, of which the basal one is coherent with the adjacent cells of the thallus, and the upper ones are free. Of the two upper cells, the lower smaller one forms the pedicel of the antheridium, the other its body. These first divisions correspond exactly to those in Sphaerocarpus, and also in some other Liverworts. The basal cell divides usually by intersecting vertical walls, and forms a group of about four cells at the base of the antheridium, but takes no further part in its development.

The subsequent divisions in the antheridium show considerable variation, and one of much interest in connexion 
with the question of the affinities of Geothallus. The first division in the upper cell, instead of being transverse as in Sphaerocarpus, is vertical or oblique, agreeing thus with the typical Jungermanniaceae. In case the first wall is vertical, it is followed by two horizontal walls (Fig. I3), and each of the four cells is again divided by vertical walls so that regular octants are formed as in Sphaerocarpus. Where the first wall is strongly inclined (Fig. I4), the secondary wall is found first in the larger of the two cells, and the effect is produced of a two-sided apical cell like that found in the typical Mossantheridium. A variation of this kind has been noted by the writer in Riccia ${ }^{1}$. Whether in any of these instances the regular octant-formation was suppressed could not be certainly determined; but certain irregularities noticed in the crosssections of the antheridium would indicate that this probably is sometimes the case.

The next divisions are generally periclinal, and effect the separation of the central mass of cells, from which later the sperm-cells develop (Figs. I5, I6). These central cells soon acquire very dense contents, which stain strongly, and divide rapidly until the full number of sperm-cells is formed. These cells are arranged in groups corresponding to the primary divisions in the antheridium, and, especially where the contents have been slightly contracted through reagents (Fig. I 7 ), show these primary divisions for a long time. The divisions occur mostly at right angles to each other, and the resulting spermcells, as so frequently happens in the Bryophytes, are nearly cubical. The nucleus of the sperm-cells is relatively large, but the sperm-cells themselves are smaller than is usual in the Jungermanniaceae. In this respect, and in the consequent small size of the spermatozoids, Geothallus recalls Riccia. Owing to their very small size, the spermatozoids do not offer a good subject for studying their development, and no attempt was made to follow this out. There was nothing to indicate any departure from the ordinary process. The free sperma-

1 Campbell, Mosses and Ferns, p. 33. 
tozoids (Fig. 20) are extremely small, and show about two coils. The tapering forward end is provided with the usual two cilia, which are almost equal in length to the body of the spermatozoid.

The stalk of the antheridium is derived from the second of the three primary cells into which the mother-cell is divided. This cell is often divided by cross-walls, so that the stalk is composed of four short rows of cells; but quite as often the second vertical division is suppressed, and it is then made of but three (Fig. I5, a). The transverse divisions are never numerous, and the pedicel remains short. In the formation of longitudinal walls in the pedicel Geothallus differs from Sphaerocarpus, where the pedicel always is composed of but a single row of cells, and resembles much more Fossombronia or Pallavicinia ${ }^{1}$, where there are also found quadrant-walls in the body of the antheridium. At maturity it is usually somewhat oblique, being bent forward more or less.

Each antheridium is surrounded by an envelope, closely resembling that found in Sphaerocarpus, and formed in exactly the same way. Almost simultaneously with the first division in the antheridium mother-cell, the superficial cells immediately begin to grow out about it in the form of a ring-shaped wall, and very soon outstrip the antheridium, which is sunk in the involucre thus formed. The wall of the involucre remains but one cell thick, except at the extreme lower part where it joins the thallus. The upper part of the envelope is prolonged into a neck, through which the spermatozoids are discharged. The enlarged lower part fits closely over the antheridium (Fig. 19).

Sometimes the antheridia are produced only in small numbers, and may form a single row occupying the median line of the shoot; but usually they are produced in larger numbers, and may almost completely cover the dorsal surface of the thallus (Fig. IO), much as in Sphaerocarpus. 
In a few cases two antheridia were seen within the same envelope. They were strongly flattened on the side where they were in contact, but there was no means of deciding whether or not they originated from a common mother-cell.

\section{The Archegonium.}

The female plant does not differ much from the male, but is possibly a little larger, as a general thing, and more freely branched (Figs. 21, 22). Like the antheridia, the archegonia arise from superficial cells near the apex of the shoot, and at first are hardly distinguishable in form from the youngest antheridia. The mother-cell of the archegonium, however, is somewhat larger and more enlarged above. The first wall corresponds to that in the young antheridium, and is nearly level with the surface of the thallus. The second wall is also horizontal, as in the antheridium, but it is formed in the lower of the two primary cells, instead of in the upper one, which becomes at once the archegonium proper, the two lower cells forming the short pedicel (Fig. 24). The form of the mother-cell of the archegonium, as well as the first division, correspond very closely with the same points in Sphaerocarpus, the greatest difference being the position of the first wall, which is higher up in Sphaerocarpus, so that later the archegonium is raised above the level of the thallus. The first divisions in the upper cell are those typical of the Liverworts in general. The usual three intersecting walls arise, cutting off the axial cell (Fig. 25), from which later the egg-cell, canal-cells, and cover-cell are developed. Then each of the primary peripheral cells is bisected by a second vertical wall, after which by horizontal walls in all the cells the archegonium-rudiment is divided into two tiers, constituting respectively the venter and neck. Before this takes place, however, the cover-cell has been. cut off from the axial cell. The archegonium now (Fig. 26) consists of six peripheral rows of cells enclosing an axial row of three cells. The cover-cell next undergoes division into four by cross-walls, and the two 
inner cells by transverse divisions give rise to the egg and the row of canal-cells. The central cells have larger nuclei and denser protoplasm than the peripheral ones. In one case (Fig. 29) apparently two ventral canal-cells had been cut off successively, and some older ones showed what seemed to be evidences of the same thing. The writer has in a former paper called attention to a very similar phenomenon observed in Osmunda ${ }^{1}$. What the significance of this is would be hard to conjecture. The suggestion made with reference to Osmunda, that possibly it was something analogous to the polar-body of the animal ovum, seems hardly in accordance with the phenomena of fertilization known in plants.

The neck-canal-cell divides first into two (Fig. 27), and later each of these divides once more. The wall of the archegonium remains single-layered until after it is fertilized. A crosssection of the neck of the archegonium shows six peripheral cells, as in Sphaerocarpus and the Marchantiaceae, instead of only five, the number in the typical Jungermanniaceae. The basal cells undergo divisions in various directions, so that the pedicel is not clearly distinguishable in the older archegonium. The venter of the ripe archegonium is not much enlarged, and the elongated egg does not completely fill its large cavity (Fig. 31).

As in Sphaerocarpus, the envelope is formed about the archegonium whether it is fertilized or not; but in Geothallus it grows more slowly at first, and at the time the archegonium opens it does not reach more than about halfway up the neck, the upper part of which projects out of the opening. Later, however, it continues to grow until it finally becomes very conspicuous (Fig. 23). Its form is decidedly more cylindrical than in Sphaerocarpus, and the opening at the top larger. As in Sphaerocarpus, the neck of the archegonium is more or less bent forward.

\footnotetext{
1892.

1 'On the Prothallium and Embryo of Osmunda', Annals of Botany, April,
} 


\section{EMBRYOGENY.}

The fertilization of the egg was not studied, as the extremely small size of the spermatozoid did not promise satisfactory results. After fertilization the egg increases in size, and the granular contents become less conspicuous. The primary division (basal wall) is transverse, and divides the egg, which still retains its elongated shape, into two cells of nearly equal height, but the lower one is more tapering than the nearly hemispherical upper one. This first division determines the separation of the capsule from the stalk, as in the Marchantiaceae and Sphaerocarpus. The primary wall is followed by a similar one in each cell, so that the embryo (Fig. 33) consists of a row of four, resembling very closely, as it does in the subsequent stages, the corresponding stages of Sphaerocarpus. The lower of the two cells derived from the hypobasal half of the embryo undergoes no further division, but remains unchanged and easily recognizable for a long time (Fig. 35). Vertical walls now arise in all of the upper cells, which usually, at least, divide each of them into four nearly equal quadrantcells (Fig. 34). Somewhat later (Figs. 35, 36) the upper part of the embryo enlarges more rapidly, and a series of periclinal walls is formed separating a central group of cells, the archesporium, from a single layer of peripheral ones which undergo no further periclinal divisions, but persist as the wall of the capsule. In the hypobasal cells the divisions are less regular, but here, too, there is unequal growth, the central part of the embryo remaining narrow, while the lower cells, by repeated division and increase in size, form a conspicuous nearly globular foot.

Owing to the small number of embryos available for study, it was not possible to determine with certainty whether the succession of the divisions in the young embryo given above is always exactly the same. Thus it is possible that a part of the short seta may arise from the epibasal portion of the embryo, as in the typical Jungermanniaceae, but there seems to be no doubt as to the hypobasal origin of the foot. Inter- 
mediate stages between those shown in Fig. 35 and Fig. 37 were wanting, so that the important point of the origin of the sporogenous and sterile cells must for the present remain undecided. A comparison of the stage shown in Fig. 37 with the corresponding one in Sphaerocarpus shows some marked differences. While the structure of the wall is the same, the wide space between the mass of archesporial cells and the wall in Sphaerocarpus is absent here, and the sporogenous cells are very much larger and entirely free, instead of being united with the sterile cells, from which they also differ much more in appearance than is the case in Sphaerocarpus. The spore-mother-cells in the specimen figured (Fig. $3^{8}, a$ ) were free globular cells with a thick membrane which appeared quite homogeneous in structure. The centrallyplaced nucleus was not very large, nor was the amount of chromatin especially noticeable. In the microtome-sections the cytoplasm showed a reticulate appearance like that observed in other similar cells, and due no doubt to the dissolving out of the oil or other soluble matter by the reagents employed in the process of imbedding. The sterile cells (Fig. $\left.3^{8,}, b\right)$ are thin-walled and almost transparent, and entirely separated from each other. They contain very little granular matter, but the nucleus is distinct.

No specimens were secured which showed the early stages in the division of the spores, and the appearance of the older spore-tetrads does not show whether or not there is any indication of the division of the cell before the nucleus divides.

\section{The Mature Sporogonium ${ }^{1}$.}

The mature sporogonium is a nearly spherical capsule, about I $\mathrm{mm}$. in diameter, connected by the very short seta, which is about four cells thick, with the enlarged bulbous foot which penetrates into the thallus, instead of being raised above it as

\footnotetext{
${ }^{1}$ For figures of the mature sporogonium and spores, see the writer's paper in the Botanical Gazette, January, 1896.
} 
in Sphaerocarpus. This is due to the more nearly sessile position of the archegonium in Geothallus. The wall of the capsule is composed of a single layer of large almost black cells, which before it ripens are filled with starch which mostly disappears later. The foot is globular or sometimes oval in outline, and its cells much distended and containing abundant protoplasm and large nuclei, showing that they are actively engaged in the nutrition of the sporogonium.

The spores are very large, and at maturity separate completely. They are nearly globular and range from $\mathrm{I} 20-\mathrm{I} 40 \mu$ in diameter. The wall is very thick, and in section shows two well-marked layers, the perinium and the exospore. An endospore of cellulose is probably present, but in microtomesections is not clearly differentiated from the inner layers of the exospore. The perinium is almost black and appears perfectly homogeneous : it is quite smooth except upon the ventral surface of the spore, where it is folded so as to produce reticulate ridges which in section have the appearance of spines. These foldings extend to the inner spore-coats as well. No chlorophyll is present in the ripe spore, but no further study of the spore-contents was made beyond noting that the nucleus is small, as is usually the case in Liverworts.

The sterile cells, which doubtless are the homologues of the elaters of the more specialized of the Hepaticae, reach a length of $48-108 \mu$, being relatively longer than the corresponding cells of Sphaerocarpus. They contain some chlorophyll and a few scattered granules apparently of albuminous nature, but little or no starch was detected in any of the specimens examined.

The sporogonium does not break through the calyptra until a much later period than in Sphaerocarpus, and traces of the calyptra remain until the sporogonium is almost ripe. The first divisions in the cells of the venter coincide pretty closely with the first wall in the embryo. Except at the base it remains two cells thick for the most part. Finally it is torn asunder by the expanding sporogium, and the upper 
part, with the neck of the archegonium, is carried up on the apex of the capsule. The basal part remains as a sheath surrounding the short seta, while the foot is completely sunk in the thallus.

\section{FORMATION OF THE TUBERS.}

The first indication of the formation of the tubers in the female plants is evident almost as soon as the first archegonium is fertilized; but in the shoots where no perfect sexual organs were developed, and in the male plants, it is of course independent of fertilization. It begins by the accumulation of granular matter in a group of interior cells near the growingpoint, which soon is very evident in section as an opaque area of varying size. This area rapidly spreads until it occupies the greater part of the axial tissue of the shoot, and its limits finally become very sharply defined. Later the chlorophyll disappears completely from these cells, and those which immediately surround the developing tuber have their walls thickened and form the rind. We have seen, however, that this rind does not extend over the growing-point itself, whose apical cell and the immediately adjacent tissue remain practically unchanged, and ready to resume active growth again when the conditions are favourable. The leaves and outer tissues of the thallus finally die, and in the fruiting plants the spores are set free by the decay of the walls of the capsule.

\section{Germination of the Spores.}

A small number of spores sown in October germinated promptly, and some of the earlier stages were seen; but another sowing made later was unsuccessful, so that the account here given is necessarily very incomplete. A very long germtube was formed in all the cases observed (Fig. 39), and into this the granular contents, largely in the form of oil-drops, pass. Very little chlorophyll is present at first, but this rapidly increases in amount. The end of the germ-tube, where the granular protoplasm becomes much denser, is cut 
off by a transverse wall. The next divisions were not seen, and in the youngest stage, found subsequently, there was a large two-sided apical cell present, which looked as if it might have been formed by the intersection of the first two walls in the terminal cell (Fig. 40). It is very probable that there is no absolute uniformity in the divisions, and that octant-divisions, such as occur frequently in most of the Marchantiaceae and Anthoceros as well as in Sphaerocarpus, may also be found. In the later stages the basal part of the thallus had assumed a cylindrical form, while the end was flattened out into a lamina but one cell thick. In Fig. $4 \mathrm{I}$ is shown one of these with a cell $(x)$ which may perhaps be the apical cell, although its lateral position might be against this. Since, however, in the still older plants studied, the growingpoint was strongly lateral, this objection is not a valid one. A most striking feature of the older plants (Fig. 42) was the presence of the leaf-like lobes which were found on either side of the growing-point and gave the thallus a most characteristic appearance, very different from the corresponding stage of Sphaerocarpus or the Marchantiaceae, and resembling more the young thallus of Anthoceros fusiformis, or still more the prothallium of Equisetum. Just at what point the two-sided apical cell of the young thallus is replaced by the form characteristic of the older one could not be determined. In none of the specimens examined was a rhizoid developed from the base of the germ-tube, but the first one grew out from one of the basal cells of the thallus itself (Fig. 42).

\section{Summary and Conclusions.}

There is little doubt that on the whole Geothallus agrees more nearly with Sphaerocarpus in its structure than with any other known form, and may very properly be placed in the same family, which also includes, according to Schiffner ${ }^{1}$, the imperfectly known Thallocarpus. Leitgeb ${ }^{2}$ unites Riella

\footnotetext{
1 The Hepaticae, in Engler and Prantl, Die Natürlichen Pflanzenfamilien, 9I, 92, p. 50 .

${ }^{2}$ Leitgeb, 1.c., iv. p. 9 .
} 
with Sphaerocarpus into the family Rielleae, but Schiffner ${ }^{1}$ makes a special family, Rielloideae, to include the genus Riella. The four genera all agree in the absence of perfect elaters, which are replaced by the thin-walled chlorophyllbearing cells, and constitute the lowest group of the anacrogynous Jungermanniaceae, the Anelatereae.

Geothallus agrees with Sphaerocarpus in the form of the apical cell, the general position and structure of the sexual organs, including the characteristic envelope with which each is surrounded. In all these particulars both genera resemble Riccia, where the transverse primary divisions in the antheridium, as well as the subsequent quadrant-divisions in the upper cells, are quite different from the corresponding divisions in the antheridium of the typical Jungermanniaceae. The six outer rows of cells in the neck of the archegonium in both genera are also suggestive of the Marchantiaceae rather than of the typical Jungermanniaceae, where there are but five. But the most important point of resemblance between Geothallus and Sphaerocarpus is the sporogonium, in both the structure and development of which they agree very closely.

The most important points in which Geothallus differs from Sphaerocarpus are-its much more massive thallus; the second division in the antheridium and the massive stalk of this organ; the sessile archegonium, and consequent deeper penetration of the foot of the embryo into the thallus; the large size and complete separation of the smooth spores; and, most important, the development of true leaves and the formation of tubers by which the plant becomes perennial. It will be remembered, however, that under certain conditions Sphaerocarpus may also develop leaf-like organs.

The points of resemblance with Riccia have already been mentioned. Among the typical anacrogynous Jungermanniaceae, Fossombronia, at least of the American genera, resembles Geothallus most closely. It differs, however, in several important particulars, apart from the very much more

${ }^{1}$ Schiffner, 1. c., p. $5^{\text {I. }}$.

M $\mathrm{m} 2$ 
highly developed sporogonium with its long seta and true elaters. The growth of the thallus is from a two-sided apical cell; the sexual organs are destitute of a special envelope; the divisions in the antheridium are those of the typical Jungermanniaceae; and the neck of the archegonium has five peripheral rows of cells.

Petalophyllum, according to Leitgeb ${ }^{1}$, agrees closely with Fossombronia in its apical growth and in the development of its leaves. The antheridia are partially surrounded by an imperfect envelope, but the archegonia are in groups. An interesting resemblance between Petalophyllum and Geothallus is the formation in the former of bulb-like structures, probably similar in nature to the tubers of Geothallus. This is associated with the burying of the thallus in the sandy soil where the plant grows ${ }^{2}$.

All of the Anelatereae show unmistakable resemblances to the lower Marchantiaceae, especially Riccia, and are probably pretty near the point at which the Marchantiaceae and Jungermanniaceae diverge. Sphaerocarpus is on the whole the most primitive type, and Geothallus may be said to be an intermediate between it and forms like Fossombronia. This is indicated both by the structure of the antheridium and the leaves. The development of leaves, however, cannot be considered as being very important as bearing upon its relationship with other forms, since this has occurred beyond question at several points in the series of Anacrogynae. It emphasizes, however, the exceedingly generalized and presumably primitive character of the whole group, and its importance in a study of the origin of the higher Archegoniates. 


\title{
EXPLANATION OF FIGURES IN PLATES XXIV AND XXV.
}

\author{
Illustrating Professor Campbell's paper on Geothallus tuberosus.
}

\section{PLATE XXIV.}

Except where otherwise stated, the drawings were made from microtomesections of material fixed with chromic acid or absolute alcohol.

Fig. I. Nearly median section of the old thallus of Geothallus tuberosus, showing the tuber, t. $\times 20$.

Fig. 2. The hinder part of the tuber, $\times 300$.

Fig. 3. Forward part of the tuber surrounded by the overlapping leaves, and showing the apical cell, $\times ; \times 300$.

Figs. 4, 5. A germinating tuber; $a$, from the side; $b$, from above; $\times 20$. $k$, the young shoot.

Fig. 6 . Vertical section of the growing-point of a young shoot, $\times 300 . \quad \times$, the apical cell ; $l$, leaves.

Fig. 7. Horizontal section of a similar apex, $\times 300 . h$, ventral hairs.

Fig. 8. Young leaf, $\times 300$. $D$, dorsal ; $V$, ventral margin.

Fig. 9. Glandular hair from the ventral surface, $\times 300$.

Fig. Io. Male plant, with numerous antheridia, $\times 20$.

Figs. II-I6. Successive stages in the development of the antheridium, $\times 600$. Fig. I5, cross-sections, the others longitudinal. In Fig. I5, $a$ is a section through the stalk, $b$ through the body of the antheridium.

Fig. I7. An older antheridium, median longitudinal section, $\times 300$.

Fig. I8. Surface-view of the cells from the wall of the older antheridium, $\times 300$.

\section{PLATE XXV.}

Fig. 19. Median longitudinal section of a nearly ripe living antheridium, showing the form of the envelope, $x$ about roo.

Fig. 20. Spermatozoids killed with osmic acid, $\times 1000$.

Fig. 21. Female plant, $\times 5$.

Fig. 22. End of one of the branches of the same, $\times 20$.

Fig. 23. Section of an older female plant, showing the archegonal envelopes (q), $\times 5$.

Figs. 24-26. Young archegonia, median longitudinal sections, $\times 600$.

Figs. 27, 28. Two longitudinal sections of an older archegonium, $\times 300$. The egg and ventral canal-cell only are shown in Fig. 28.

Fig. 29. Venter of an archegonium, with two ventral canal-cells, $V^{1}, V^{2}$, $\times 300$.

Fig. 30. Longitudinal section of an open but unfertilized archegonium, $\times 300$.

Fig. 31. Venter of an open archegonium, showing the recently fertilized egg, $\times 300$. 


\section{Campbell.-Development of Geothallus tuberosus.}

Fig. 32. Cross-section of the neck of the archegonium, $\times 300$.

Fig. 33. A four-celled embryo, enclosed in the venter of the archegonium, $\times 300$.

Fig. 34. Longitudinal section of an older embryo, $\times 300$.

Fig. 35. Similar section of an older embryo, showing the calyptra, $\times 300$.

Fig. 36. Two transverse sections of an embryo of about the same age as that shown in Fig. 35, $\times 300 . a$ is the apical region; $b$ is lower down.

Fig. 37. A section through the upper part of a young sporogonium, after the separation of the spore-mother-cells, $\times 50$.

Fig. 38. A spore-mother-cell and two sterile cells from the same sporogonium, $\times 300$.

Fig. 39. A germinating spore, $\times$ roo.

Fig. 40. Apex of very young thallus, showing the two-sided apical cell, $x$; $g$, the germ-tube ; $\times 300$.

Fig. 4I. A somewhat older stage, $\times 300$.

Fig. $4^{2}$. Young plant still showing the germ-tube, $g$, and spore, $s p, \times 40$. $x$, the growing-point of the thallus. 


\section{Annals of Botany}

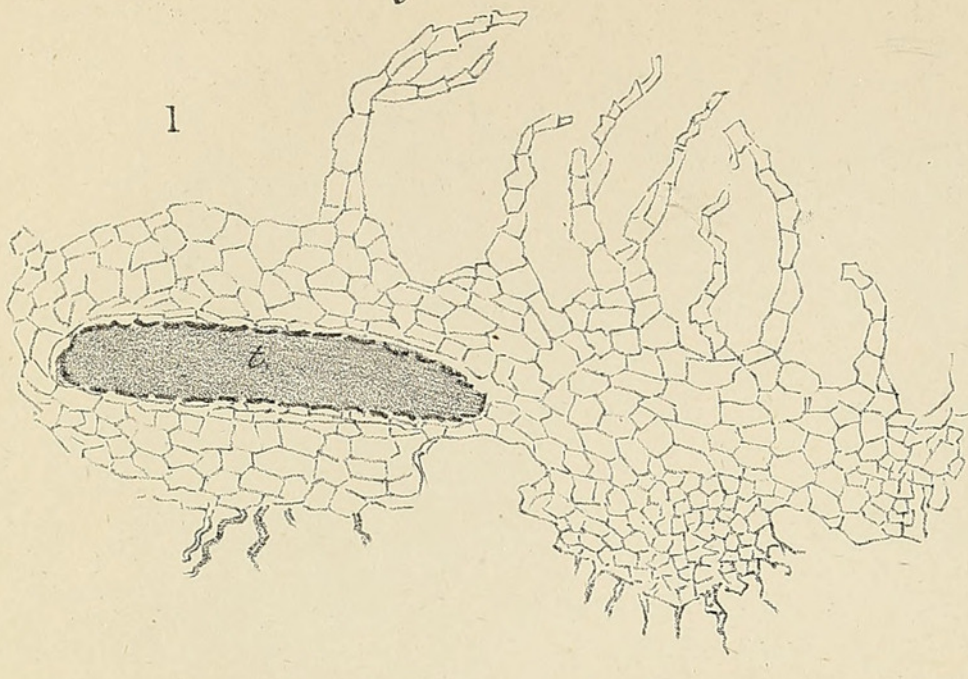

4

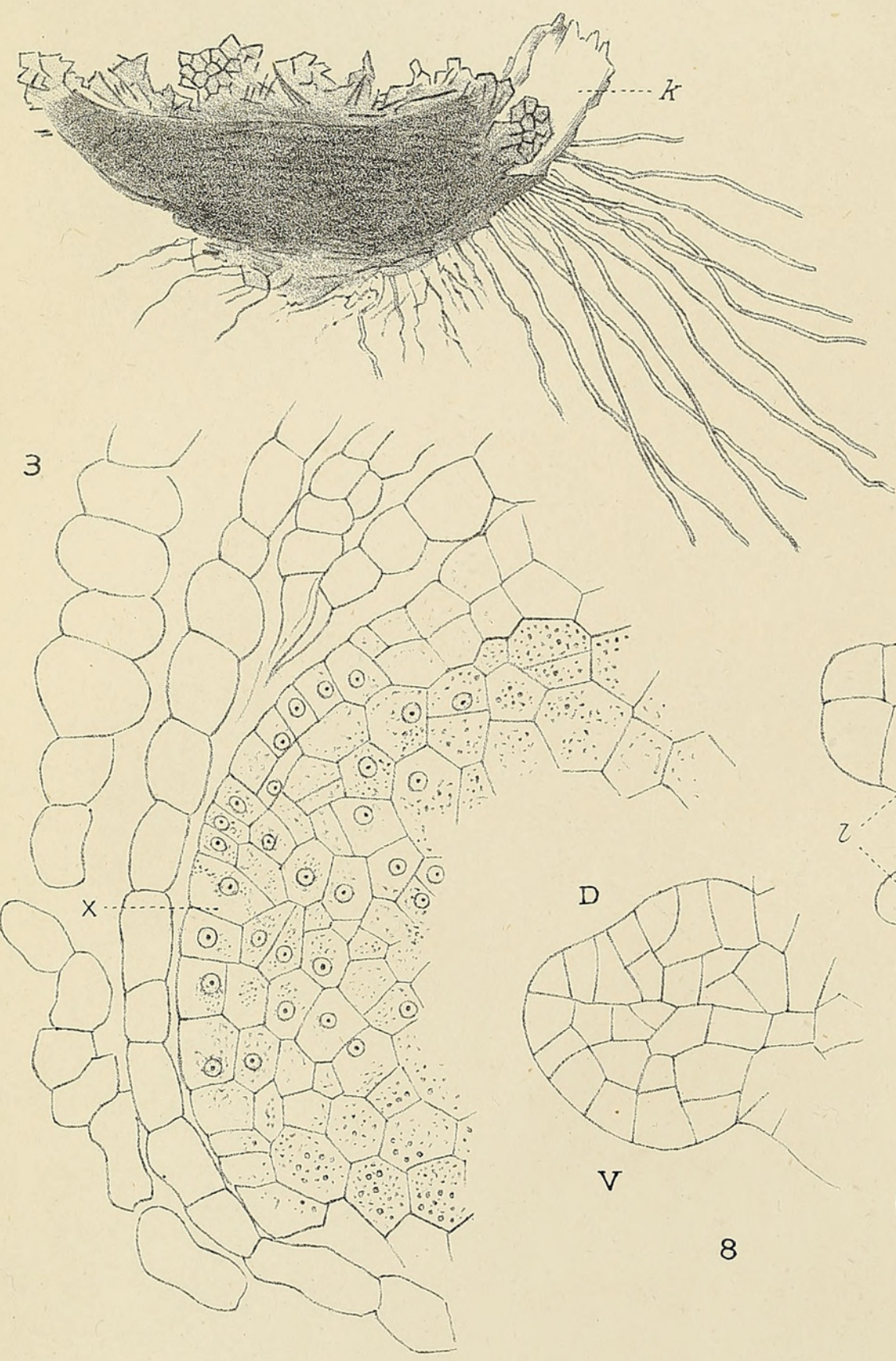

D.H.Campbell del 

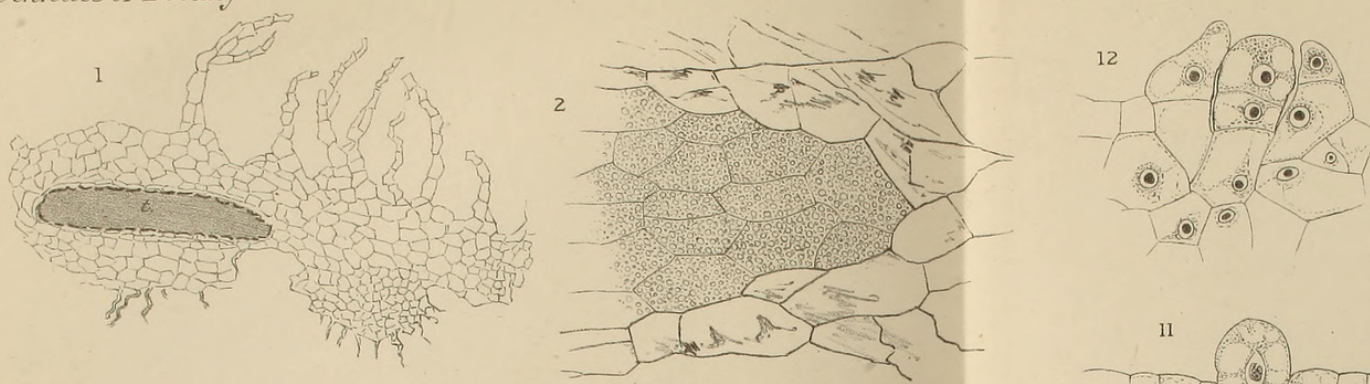

Vol.X, Pl.XXIV.

4
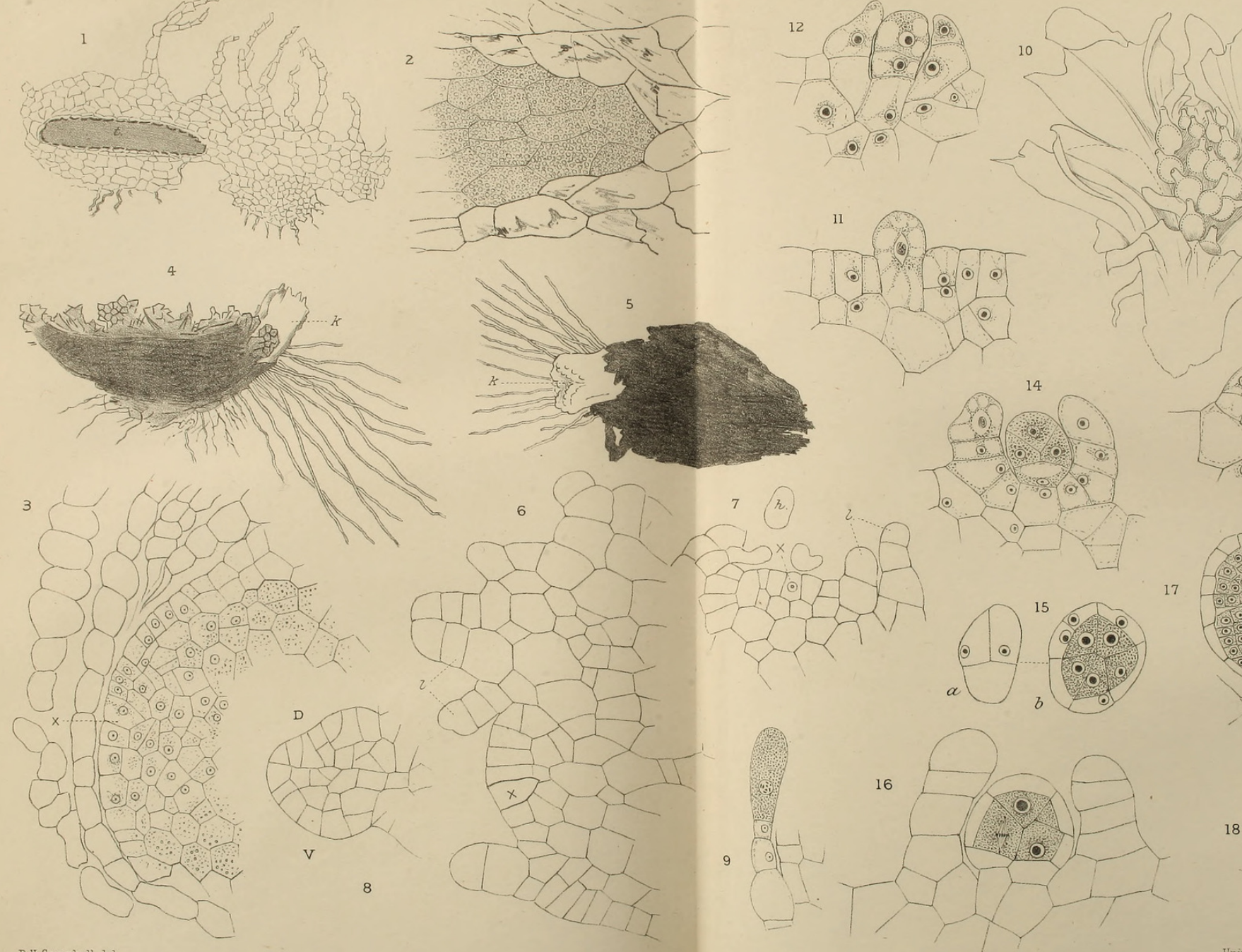

73
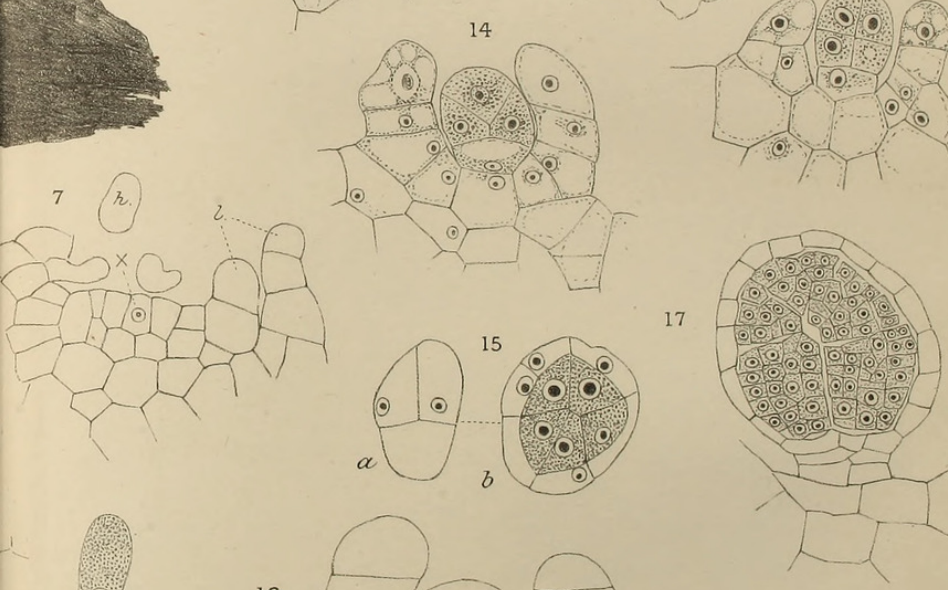
Annals of Botany

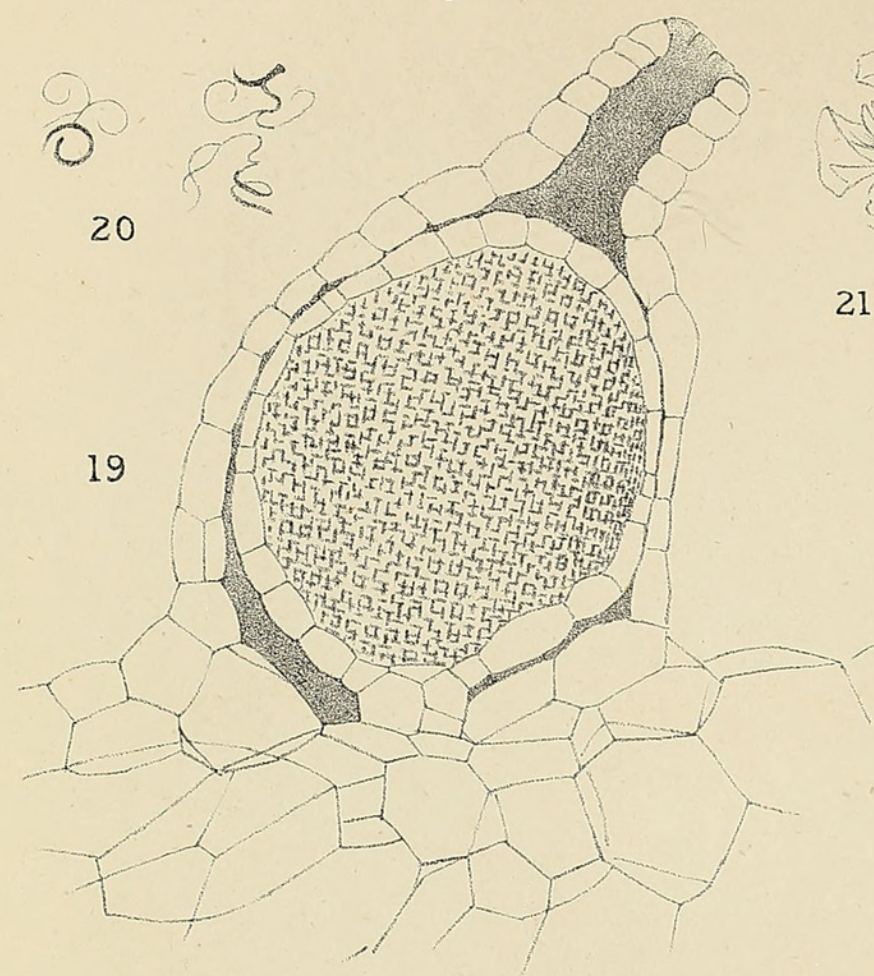

21
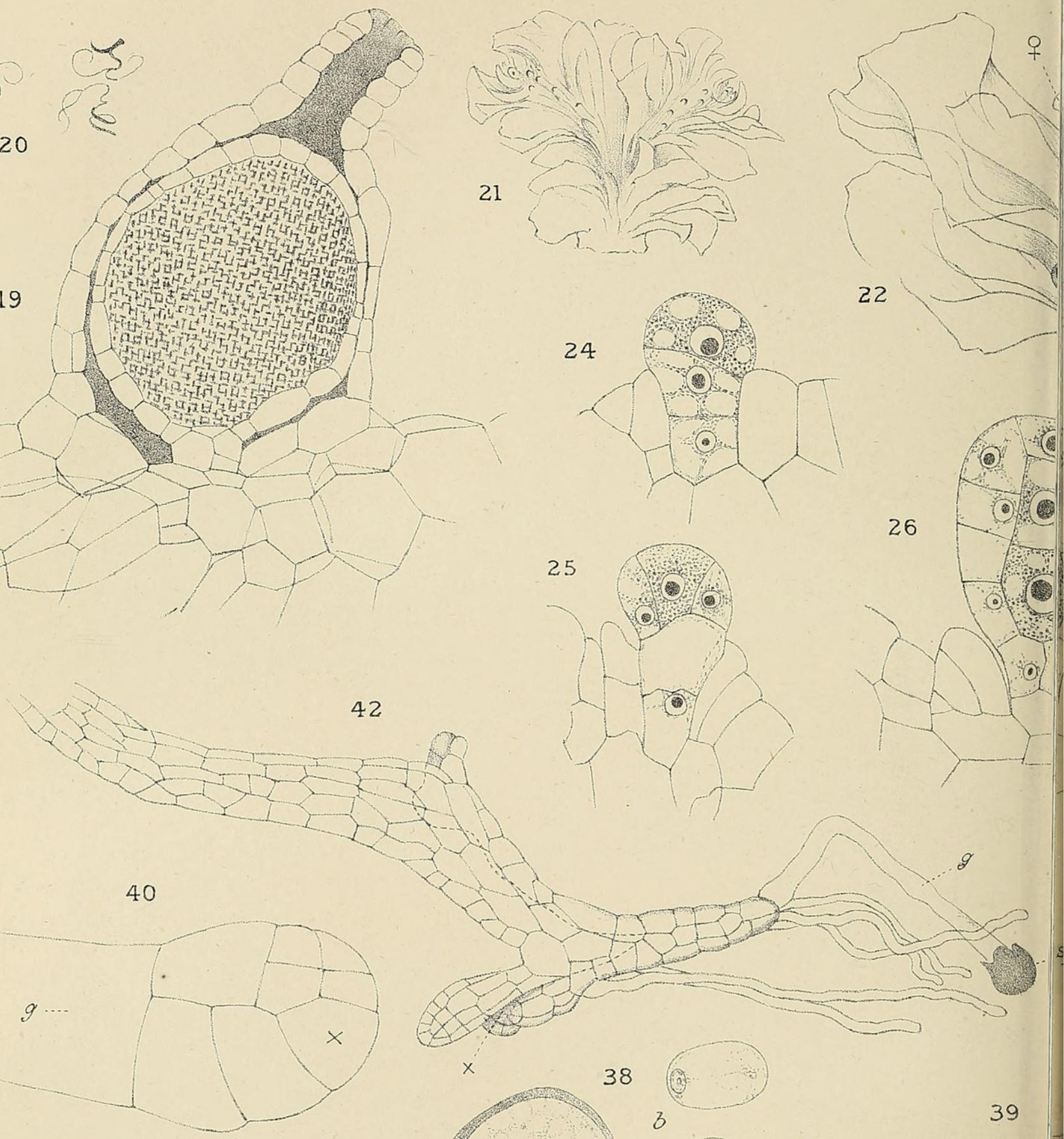

41

3

39
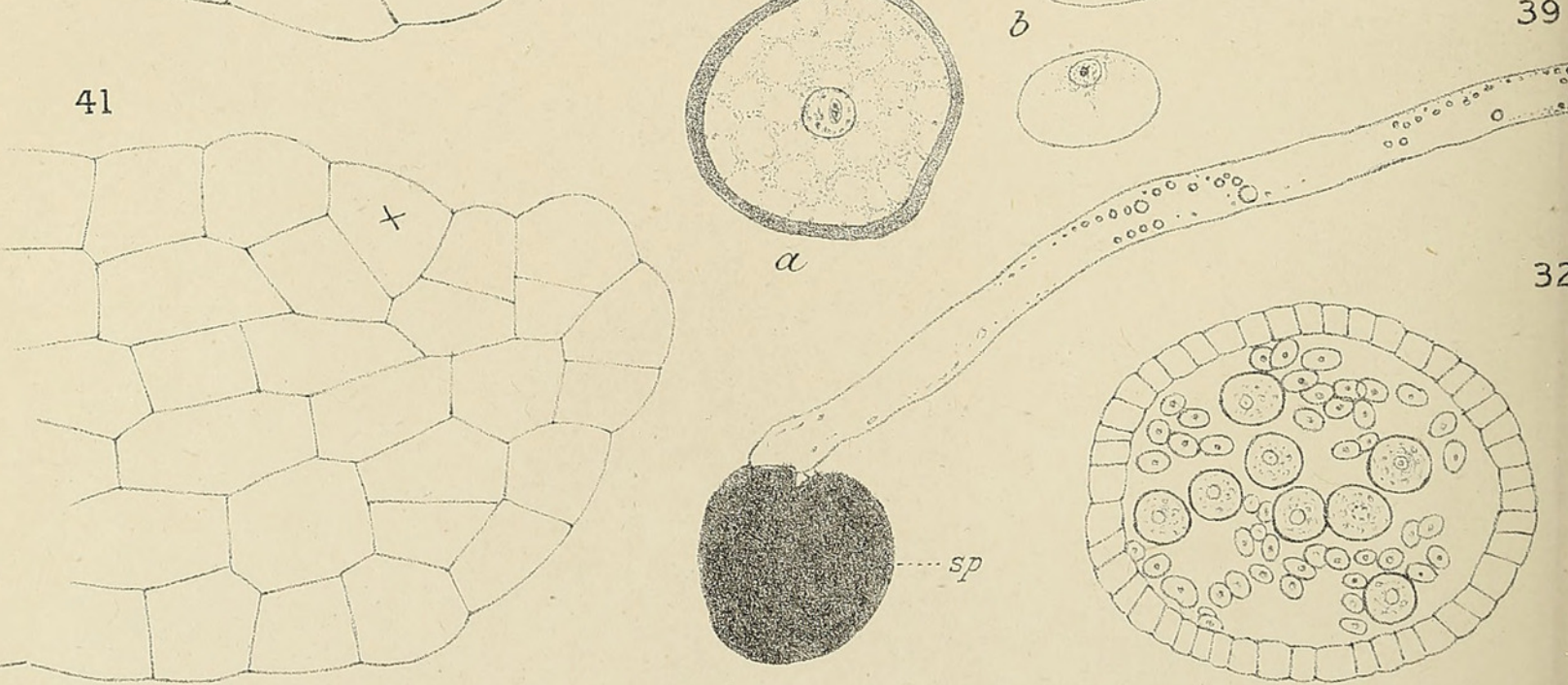

D. H. Campbell del.

CAMPBELL. - GEOTHALLUS. 


\section{Annals of Botany}
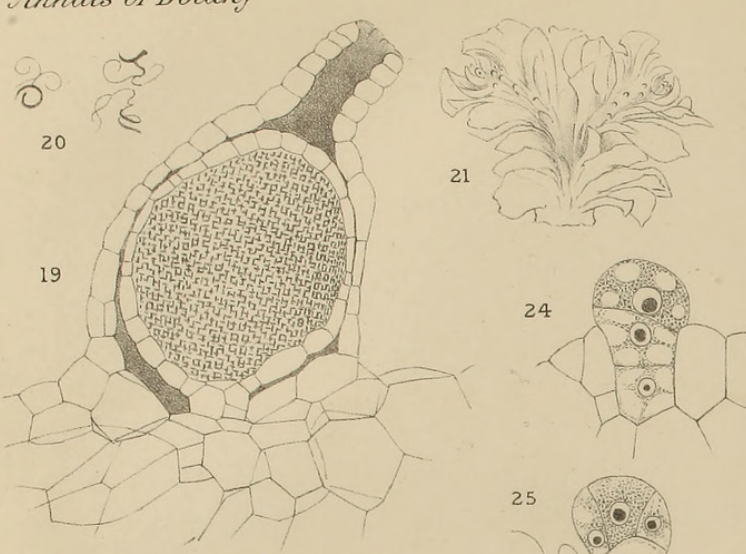

22
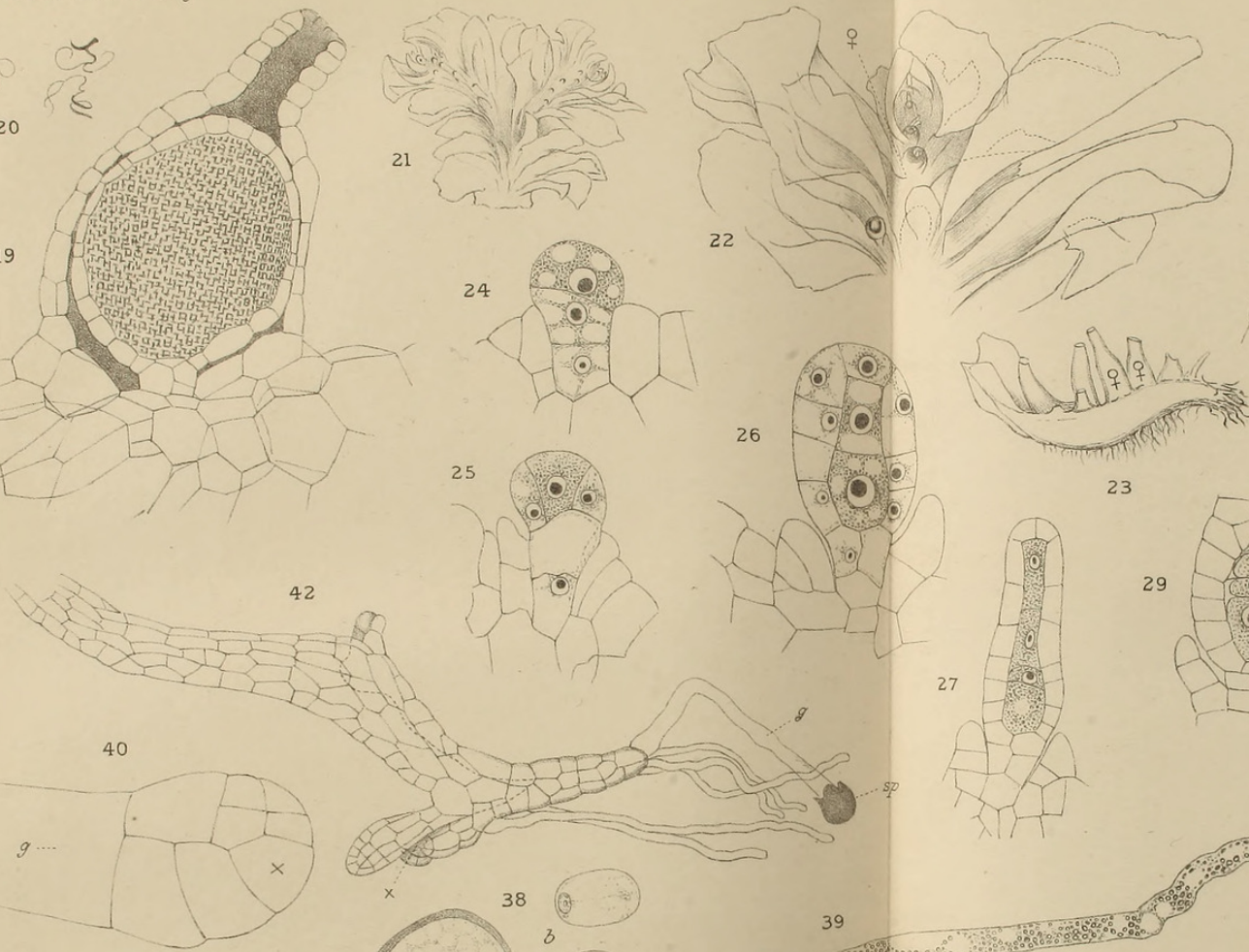

41
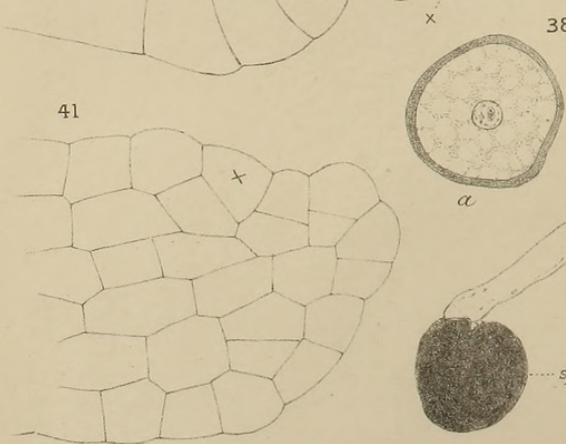

sp

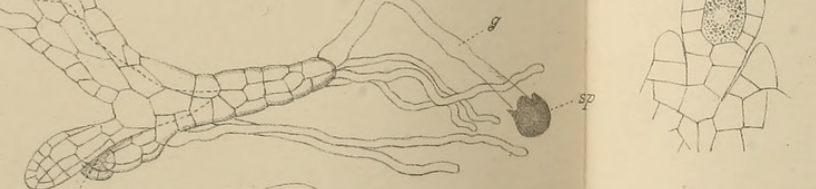

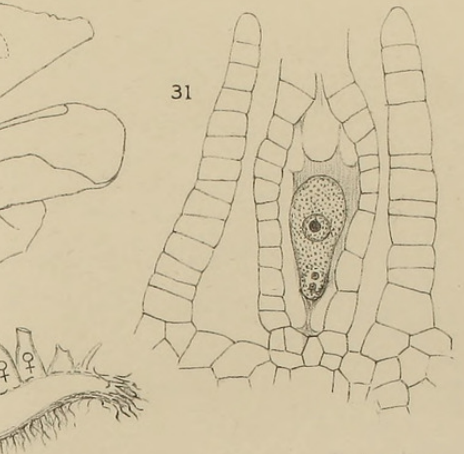

D H. Campbell del.

CAMPBELL. - GEOTHALLUS. 


\section{$2 \mathrm{BHL}$ Biodiversity Heritage Library}

Campbell, Douglas Houghton. 1896. "The development of Geothallus tuberosus, Campbell." Annals of botany 10, 489-510. https://doi.org/10.1093/oxfordjournals.aob.a088624.

View This Item Online: https://www.biodiversitylibrary.org/item/235772

DOI: https://doi.org/10.1093/oxfordjournals.aob.a088624

Permalink: https://www.biodiversitylibrary.org/partpdf/318436

\section{Holding Institution}

Smithsonian Libraries

\section{Sponsored by}

Biodiversity Heritage Library

\section{Copyright \& Reuse}

Copyright Status: Not in copyright. The BHL knows of no copyright restrictions on this item.

This document was created from content at the Biodiversity Heritage Library, the world's largest open access digital library for biodiversity literature and archives. Visit BHL at https://www.biodiversitylibrary.org. 